\title{
IMPLEMENTASI KEBIJAKAN PROGRAM KOTAKU (KOTA TANPA KUMUH) DALAM UPAYA MENINGKATKAN KESEJAHTERAAN MASYARAKAT
}

\author{
Nurhasanah \\ Fakultas Ilmu Administrasi, Universitas Islam Malang \\ email: hasanahn765@gmail.com
}

\begin{abstract}
ABSTRAK
Program KOTAKU (Kota tanpa Kumuh) adalah program penanganan pemukiman kumuh menjadi pemukiman yang layak huni di perkotaan, melalui pembangunan infrastruktur berbasis masyarakat yang memberikan peranan masyarakat yang lebih besar. Tujuan dari penelitian ini adalah: (1) Untuk mengetahui bagaimana implementasi kebijakan program KOTAKU dalam meningkatkan kesejahteraan masyarakat. (2) untuk mengetahui faktor pendukung dan penghambatyang di hadapi dalam implementasi kebijakan program KOTAKU dalam meningkatkan kesejahteraan masyarakat. Untuk mencapai tujuan tersebut, dalam penelitian ini menggunakan jenis penelitian kualitatif dengan pendekatan deskriptif. Lokasi penelitian ini di laksanakan di Kelurahan Merjosari Kecamatan Lowokwaru Kota Malang. Objek yang diteliti pada penelitian ini adalah Implementasi Kebijakan Program KOTAKU (Kota Tanpa Kumuh). Program ini untuk meningkatkan akses terhadap infrastruktur dan pelayanan dasar di kawasan kumuh perkotaan untuk mendukung terwujudnya pemukiman perkotaan yang layak huni, produktif dan berkelanjutan. Adapun faktor penghambat dari program KOTAKU adalah kurangnya partisipasi masyarakat dalam keikutsertaan dalam pelaksaan kegiatan program KOTAKU. Faktor pendukung dari program KOTAKU masih ada sebagian masyarakat yang masih ikut berpartisipasi dalam kegiatan program KOTAKU bahkan dengan sukarela memberikan bantuan berupa tenaga maupun materi.
\end{abstract}

Kata kunci: implementasi kebijakan, program kotaku, kendala

\section{PENDAHULUAN}

\section{Latar Belakang}

Didalam pertumbuhan penduduk yang terjadi diindonesia khususnya diperkotaan yang berlangsung dengan pesat menimbulkan dampak dari berbagai aspek kehidupan bangsa terutama diwilayah perkotaan. Salah satu aspek yang sangat terasa adalah dengan semangkin sulitnya untuk memenuhi beberapa kebutuhan rumah ataupun tempat tinggal bagi warga atau penduduk itu sendiri. Yang tersebut disebabkan karena terbatasnya kemampuan untuk membangun pemukiman yang layak bagi warga untuk memenuhi dan mencukupi beberapa syarat.

Bagi kota besar persoalan pemukiman kumuh merupakan masalah yang serius karena dikhawatirkan dapat menyebabkan terjadinya pemukiman kumuh yang meningkat, kemudian menyebabkan lahirnya berbagai persoalan sosial diluar kontrol ataupun kemampuan pemerintah kota untuk mengatasi masalah tersebut dengan penduduk yang semakin bertambah dengan disertai urbanisasi yang tinggi sehingga masalah pembangunan dalam hal ini dengan penyediaan sarana pemukiman menjadi semakin mendesak terutama didaerah perkotaan. 
Beragam upaya dan program yang dilakukan pemerintah untuk mengatasinya namun masih saja dijumpai pemukiman masyarakat miskin di hampir setiap sudut kota yang disertai dengan ketidaktertiban dalam hidup bermasyarakat di perkotaaan misalnya yaitu pendirian rumah maupun kios dagang secara liar dilahan -lahan pinggir jalan sehingga mengganggu ketertiban lalu lintas akhirnya menimbulkan kemacetan jalanan kota.

Salah satu program yang dilakukan pemerintah untuk mengatasi masalah pemukiman kumuh di perkotaan yaitu dengan melaksanakan program Kota Tanpa Kumuh (KOTAKU) adalah program yang dilaksanakan pemerintah secara nasional di 269 kota/kabupaten di 34 Propinsi yang menjadi "platfrom" atau basis penanganan kumuh yang menitrgrasi berbagai sumber daya dan sumber pendanaan, termasuk dari pemerintah pusat, provinsi, kota /kabupaten, swasta, masyarakat, dan pemangku kepentingan lainya. KOTAKU sendiri bertujuan untuk membangun sistem yang terpadu untuk penanganan kumuh, dimana pemerintah daerah memimpin dan berkolaborasi dengan para pemangku kepentingan dalam perencanaan maupun implemantasinya.

Salah satu Kota yang termaksuk dalam pemukiman kumuh adalah Kota Malang. Sampai saat ini Kota Malang. menghadapi persoalan terkait pemukiman kumuh. Berdasarkan data Pemerintah Kota Malang pemukiman kumuh mencapai 608,9 hektar yang tersebar di 29 titik. Pemukiman kumuh paling banyak tercatat di Kelurahan Bareng yakni seluas 81, 56 hektar. Posisi kedua yakni Kelurahan Ciptomulyo dengan 62,2 hektar lahan pemukiman kumuh. Dalam penanganan pemukiman kumuh di tiap Kelurahan harus dilakukan secara bertahap.

Kelurahan Merjosari yang memiliki banyak potensi perekonomian banyaknya PKL, kosan, dan sumber daya masyarakat dan semua kegiatan industri selain berdagang dan berbisnis kos-kosan yang berfungsi sebagai roda penggerak perekonomian. Namun dengan potensi yang ada Kelurahan Merjosari juga memiliki banyak permasalahan lingkungannya yaitu banjir, sampah, drainase yang kurang maksimal dan belum adanya septitank sehingga pembuangan kotoran langsung di buang di sungai. Untuk masalah tersebut diatasi dengan adanya program KOTAKU.

Tahapan pelaksanaan KOTAKU meliputi tahapan pendataan, dimala lembaga masyarakat di desa/ kelurahan yang bernama Badan/ Lembaga Keswadayaan Masyarakat (BKM/LKM), sudah melakukan pendataan kondisi awal (baseline) 7 indikator kumuh di desa/kelurahan masing-masing. Setelah itu disusun dokumen perencanaan yang terintegrasi antara dokumen perencanaan masyarakat dengan dokumen perencanaan kabupaten/kota. Hasil perencanaan ini menentukan kegiatan prioritas untuk mengurangi permukiman kumuh dan mencegah timbulnya permukiman kumuh baru, yang akan dilaksanakan, baik oleh masyarakat atau oleh pihak lain yang memiliki keahlian dalam pembangunan infrastruktur pada entitas kawasan dan kota.

\section{Rumusan Masalah}

Berdasarkan uraian dan penjelasan latar belakang diatas, maka dapat dirumuskan beberapa rumusan masalah yang akan dikaji oleh peneliti yakni:

a. Bagaimanakah implementasi kebijakan program KOTAKU dalam upaya mensejahterakan masyarakat di Kelurahan Merjosari?

b. Faktor pendukung dan faktor penghambat yang di hadapi dalam implementasi kebijakan program KOTAKU dalam upaya meningkatkan kesejahteraan masyarakat di Kelurahan Merjosari? 


\section{Tujuan Penelitian}

Adapun tujuan dari penelitian ini adalah untuk:

a. Untuk mengetahui bagaimana implementasi kebijakan program KOTAKU dalam meningkatkan kesejahteraan masyarakat.

b. Untuk mengetahui faktor pendukung dan penghambat yang di hadapi dalam implementasi kebijakan progam KOTAKU dalam meningkatkan kesejahteraan masyarakat.

\section{Manfaat Penelitian}

a. Manfaat Teoritis

$>$ Bagi jurusan administrasi publik dapat menambah pengetahuan dan wawasan dalam hal mengenai implemantasi kebijakan program KOTAKU.

> Bagi administrasi publik dapat dipakai sebagai referensi lanjutan untuk peneliti lain yang akan mengkaji secara mendalam tentang implementasi kebijakan program KOTAKU.

$>$ Bagi penulis agar mengetahui dan menambah wawasan dalam memahami implementasi kebijakan program KOTAKU.

\section{b. Manfaat Praktis}

$>$ Penelitian ini diharapkan dapat memberikan konstribusi terhadap implementasi tentang program KOTAKU.

> Penelitian ini di harapkan dapat memberikan konstribusi terhadap pemerintah, lembaga swadaya masyarakat, maupun stakeholder lainnya terhadap implementasi program KOTAKU.

\section{METODE PENELITIAN}

\section{Jenis Penelitian}

Penelitian ini bertujuan untuk menemukan, memahami, menjelaskan, dan memperoleh gambaran fenomena-fenomena yang dikaji. Oleh karena itu itu peneliti menggunakan jenis penelitian kualitatif. Metode penelitian adalah suatu cara yang dipergunakan untuk melalakukan kegiatan ilmiah yang berupa penyelidikan yang dilakukan secara berhati-hati. Penelitian ini bertujuan untuk menganalisis implementasi kebijakan Program KOTAKU di Kelurahan Merjosari.

Jenis penelitian yang di ambil penulis adalah dengan menggunakan penelitian kualitatif. Penelitian kualitatif adalah penelitian yang bermaksud untuk fenomena tentang apa yang dialami oleh subjek penelitiannya misalnya perilaku, presepsi, motivasi, tindakan dan lain-lain. Secara holitis dengan cara deskripsi dalam bentuk katakata dan bahasa., pada suatu konteks khusus yang alamiah dan dengan memanfaatkan berbagai metode ilmiah dengan pendekatan kualitatif maka data yang diperoleh lebih lengkap, lebih mendalam dan bermakna sehingga tujuan peneliti dapat di capai.

\section{Fokus Penelitian}

Fokus penelitian ialah dimana pusat perhatian dari apa yang akan diteliti untuk mendapatkan data yang akan dikumpulkan, diolah, dianalisis, dan interpretasikan sesuai dengan masalah yang ada dengan batasan- batasan tertentu. Menurut Moleong (2008:4) pendekatan fokus penelitian dalam pendekatan kualitatif memiliki beberapa tujuan utama yaitu penetapan fokus penelitian dapat membatasi studi, penetapan fokus penelitian sebagai fungsi untuk memenuhi kriteria untuk memasukan atau mengeluarkan suatu informal yang baru diperoleh dilapangan.

Dalam hal ini yang menjadi fokus penelitiannya adalah 
a. Implementasi Program KOTAKU (Kota Tanpa Kumuh) dalam mensejahterakan masyarakat di Kelurahan Merjosari sub fokus:

$>$ Implementasi program KOTAKU.

$>$ Model implementasi kebijakan program KOTAKU.

b. Faktor pendukung dan penghambat dalam implementasi program KOTAKU (Kota Tanpa Kumuh) dalam meningkatkan kesejahteraan masyarakat di Kelurahan Merjosari dengan sub fokus:

> Faktor pendukung yang di hadapi dalam melaksanakan implementasi kebijakan program KOTAKU.

$>$ Faktor penghambat yang di hadapi dalam melaksanakan implementasi kebijakan program KOTAKU.

\section{Situs dan Latar}

Adapun yang dimaksud dengan latar penelitian adalah letak dimana penelitian akan dilakukan, untuk memperoleh data atau informasi yang diperlukan dan berkaitan dengan permasalahan tersebut. Upaya untuk menentukan latar penelitian dan situasi penelitian merupakan kegiatan yang sangat berpengaruh terhadap pelaksanaan penelitian.

Lokasi yang di ambil dalam penelitian ini adalah Kelurahan Merjosari Kecamatan Lowokwaru Kota Malang. Situs penelitian adalah letak sebenarnya dimana peneliti mengadakan penelitian untuk mendapatkan data yang valid, akurat serta benar-benar deperlakukan dalam penelitian dan situs penelitiannya adalah Badan Keswadaan Masyarakat Kelurah Merjosari.

\section{Jenis dan Sumber Data}

Sumber data merupakan sumber yang memungkinkan untuk diperoleh segala bentuk informasi baik itu berupa data maupun lisan tentang beberapa hal yang menjadi pusat perhatian. Menurut Lofland yang dikutip oleh Moleong (2002:11) sumber data dalam penelitian kualitatif adalah kata-kata dan tindakan, selebihnya data-data tambahan dokumen, foto, fan lain-lain. Dalam penelitian ini peneliti memperoleh dua jenis data yaitu:

a. Data primer adalah hasil wawancara dengan reponden berupa kata-kata, tindakan, keterangan serta informasi yang dikumpulkan serta mengamati dan mencatat kejadian yang terjadi dilapangan. Yang menjadi sumber data primernya yaitu aparat pelaksana dan masyarakat setempat.

b. Data Sekunder adalah dokumen-dokumen seperti studi pustaka yang digunakan untuk memperoleh data dan informasi yang berhubungan menunjang dengan permasalahan penelitian. Data dan informasi diperoleh melalui studi daftar pustaka melalui buku, lapangan, penelitian, karya ilmiah, dokumen-dokumen, table, gambar, arsip, pihak terkait, catatan-catatan artikel dan lain-lain. Yang menjadi sumber data sekunder yaitu Kelurahan Merjosari Kecamatan Lowokwaru Malang.

\section{Teknik Pengambilan Sampling}

Teknik sampling adalah sebuah metode atau cara yang dilakukan untuk menentukan jumlah dan anggota sampel. Setiap anggota tentu saja wakil dari populasi yang dipilih setelah dikelompokkan berdasarkan kesamaan karakter. Teknik sampling yang digunakan juga harus disesuaikan dengan tujuan dari penelitian.

Hal yang perlu diperhatikan dalam pengambilan sampel atau sampling adalah seluruh variabel yang berkaitan dengan penelitian. Unsur-unsur khusus yang melekat 
pada pribadi tentu saja perlu diperhatikan karena individu dengan kemampuan khusus dalam sampel akan membawa bias data dan tentu saja mempengaruhi distribusi data yang ada. Kesesuaian karakteristik daerah, tingkatan, dan juga kecenderungan khusus juga perlu dipertimbangkan dalam memilih teknik sampling yang sesuai.

\section{Teknik Pengumpulan Data}

Pengumpulan data dalah prosedur yang sistematik dan standar untuk memperoleh data yang diperlukan. Teknik pengumpulan data yang di gunakan oleh peneliti sebagai berikut:

a. Observasi

Observasi adalah metode yang digunakan dengan cara pengamatan dan pencatatan secara sistematis dengan fenomena-fenomena yang di teliti. Karena metode ini paling banyak digunakan tidak hanya didunia keilmuwan, tetapi juga dalam berbagai aktivitas kehidupan. Secara umum observasi berarti pengamatan, penglihatan. Sedangkan secara khusus observasi.

b. Wawancara

Wawancara yaitu mengadakan tanya jawab secara mendalam antara peneliti dengan responden tentang persoalan atau fokus peneliti. Wawancara juga sering disebut dengan interview atau kuesioner lisan. Dalam penelitian ini peneliti menggunakan metode wawancara dalam bentuk interview bebas terpimpin. Wawancara dapat dikelompokan menjadi 2 yaitu:

> Wawancara terstruktur yang merujuk pada situasi dimana seorang pewancara mengajukan pertanyaan yang sudah di terapkan dengan kategori jawaban di setiap responden.

$>$ Wawancara tidak terstruktur merujuk pada pemahaman suatu perilaku yang komplek dari responden tanpa memberlakukan suatu kategori yang membatasi.

c. Dokumentasi

Teknik ini dilakukan untuk mendapatkan bahan yang berupa data dari dokumen baik berupa cacatan, tabel-tabel, gambar-gambar serta dokumen dalam bentuk lain yang hubungannya dengan pelaksanaan. Dalam pelaksanaan metode dokumentasi, peneliti menyelidiki benda-benda tertulis seperti buku-buku, majalah dokumen, peraturan, notulen rapat, catatan harian dan sebagainya.

\section{Keabsahan Data}

Trianggulasi adalah cara yang paling umum digunakan dalam penjaminan validitas data dalam penelitian kualitatif. Trianggulasi merupakan teknik pemeriksaan keabsahan data dengan memanfaatkan sesuatu yang lain diluar data itu untuk keperluan pengecekan data atau sebagai pembanding terhadap data tersebut.

Menurut Sugiyono (2006:267), Validitas merupakan “derajat ketetapan antara data yang terjadi pada objek penelitian dengan daya yang dapat dilaporkan oleh peneliti". Menurut Hamidi (2004:82-83), Ada beberapa teknik yang dapat digunakan untuk mengetahui validitas data, yaitu:

a. Teknik trianggulasi antar sumber data, teknik pengumpulan data, dan pengumpulan data yang dalam hal ini peneliti akan berupaya mendapatkan rekan atau pembantu dalam penggalian data dari warga di lokasi-lokasi yang mampu membantu setelah diberi penjelasan.

b. Pengecekan kebenaran informasi kepada para informan yang telah ditulis oleh peneliti dalam laporan penelitian (member check). 
c. Akan mendiskusikan dan menyeminarkan dengan tema sejawat di jurusan tempat penelitian belajar termasuk koreksi di bawah para pembimbing.

d. Perpanjangan waktu penelitian. Cara ini akan ditempuhselain untuk memperoleh bukti yang lebih lengkap juga untuk memeriksa konsistensi tindakan para informan.

\section{Analisis Data}

Analisis data merupakan bagian yang sangat penting dalam metode ilmiah karena dengan analisa data dapat diberi arti, makna yang berguna dalam memecahkan masalah penelitian itu sendiri. Data yang diperoleh peneliti dalam penelitian ini akan disajikan dalam bentuk deskriptif kualitatif. Proses analisis data dimulai dengan menelaah seluruh data yang tersedia dari berbagai sumber, baik dari wawancara pengamatan yang dituliskan dalam catatan lapangan dilokasi penelitian, dokumen pribadi, dokumen resmi, gambar, foto dan sebagainya. Analisis data kualitatif adalah proses mencari serta menyusun secara sistematis data yang diperoleh dari hasil wawancara, cacatan lapangan dan bahan-bahan lainnya sehingga dapat mudah di pahami agar dapat di informasikan kepada orang lain. Tujuan akhir dari analisis data kualitatif adalah untuk memperoleh makna, menghasilkan pengertian-pengertian, konsep-konsep serta mengembangkan hipotesis atau teori baru.

Spradley (1980) membagi analisis data dalam penelitian berdasarkan tahapan penelitian kualitatif dan lebih lanjut akan diperjelas penegertian dan langkah-langkah penelitian kualitatif. Terdapat tahapan analisis data yang dilakukan penelitian kualitatif yaitu:

a. Analisis domain (Domain analysis)

Analisis domain pada hakikatnya adalah upaya peneliti untuk memperoleh gambaran umum tentang data untuk menjawab fokus penelitian. Ditemukan berbagai domain atau kategori. Diperoleh dengan pertanyaan grand dan minitour. Peneliti menetapkan domain tertentu sebagai pijakan untuk meneliti selanjutnya. Makin banyak domain yang dipilih, maka akan semakin banyak waktu yang diperlukan untuk penelitian.

b. Analisis taksonomi (Taxonomic analysis)

Pada tahap analisis taksonomi, peneliti berupaya memahami domain-domain tertentu sesuai fokus masalah atau sasaran penelitian. Masing-masing domain mulai dipahami secara mendalam, dan membaginya lagi menjadi sub-domain, dan dari sub-domain itu dirinci lagi menjadi bagian-bagian yang lebih khusus lagi hingga tidak ada lagi yang tersisa, alias habis (exhausted).

c. Analisis kompenensial (Componential analysis)

Pada tahap ini peneliti mencoba mengkontraskan antar unsur dalam ranah yang diperoleh. Unsur-unsur yang kontras dipilah-pilah dan selanjutnya dibuat kategorisasi yang relevan. Kedalaman pemahaman tercermin dalam kemampuan untuk mengelompokkan dan merinci anggota sesuatu ranah, juga memahami karakteristik tertentu yang berasosiasi. Dengan mengetahui warga suatu ranah, memahami kesamaan dan hubungan internal, dan perbedaan antar warga dari suatu ranah, dapat diperoleh pengertian menyeluruh dan mendalam serta rinci mengenai pokok permasalahan. Ciri spesifik pada setiap struktur internal dengan cara mengkontraskan antar elemen. Dilakukan melalui observasi dan wawancara terseleksi dengan pertanyaan yang mengontraskan.

d. Analisis tema kultural (Discovering cultural theme)

Analisis Tema Kultural adalah analisis dengan memahami gejala-gejala yang khas dari analisis sebelumnya. Analisis ini mencoba mengumpulkan sekian banyak tema, 
fokus budaya, nilai, dan simbol-simbol budaya yang ada dalam setiap domain. Pada tahap ini yang dilakukan oleh peneliti adalah: (1) membaca secara cermat keseluruhan catatan penting, (2) memberikan kode pada topik-topik penting, (3) menyusun tipologi, (4) membaca pustaka yang terkait dengan masalah dan konteks penelitian.

\section{HASIL DAN PEMBAHASAN}

\section{Tahap Perencanaan}

Program KOTAKU sebagai upaya meningkatkan akses terhadap infrastruktur dan pelayanan dasar di kawasan kumuh perkotaan untuk mendukung terwujudnya pemukiman perkotaan yang layak huni dalam rangka pencapaian tujuan tersebut. Penyusunan perencanaan penanganan pemukiman kumuh di tingkat kota/kabupaten dan di tingkat masyarakat kelurahan. Perencanaan di tingkat kota di sebut RP2KP (Rencana penanganan pemukiman kumuh perkotaan) sedangkan di tingkat masyarakat atau kelurahan di sebut sebagai RPLP (Rencana penataan lingkungan permukiman) atau RKM (Rencana kerja masyarakat). Adapun penjelasan dari masing-masing perencanaan tersebut yaitu:

a. RP2KP, merupakan dokumen perencanaan penanganan pemukiman kumuh tingkat kota yang berjangka waktu 5 tahun, yang merupakan komitmen multi-aktor dan multi-sektor. Dokumen ini disusun oleh pemerintah kabupaten atau kota, pokja PKP, dengan melibatkan masyarakat dan di dukung oleh tenaga ahli perenacaan kota. Bila lingkungan kumuh berada diwilayah yang sangat berisiko bencana tinggi atau kumuh berat dan tidak ada ada alternatif lain, maka kemungkinan untuk pemukiman kembali atau relokasi dapat dieksplorasi sebagai pilihan terakhirdengan proses konsultasi antara pemerintah daerah dan masyarkat untuk mencari solusi.

b. RPLP adalah dokumen rencana penataan lingkungan pemukiman tingkat kelurahan / desa berjangka waktu 5 tahun yang merupakan penjabaran RP2KP serta disusun oleh masyarakat, didampingi oleh pemerintah daerah, fasilitator, dan tim ahli perencanaan kota. Prioritas kegiatan lingkungan akan di buatkan DED (Detailed Engineering Design) untuk infrastruktur tersier, dan untuk pelaksanaan kegiatan ekonomi, beberapa lokasi terpilih akan menyusun Rencana Aksi Pengembangan Penghidupan Berbasis Masyarakat.

\section{Survei Lokasi}

Tahap ini merupakan tahap yang penting dalam menggunakan data dan infiormasi yang sama dari hasil konsolidasi data berbagai sektor dan aktor terkain pemukiman dan perumahan. Di dalam tahap survei lokasi ini dalam penanganan pemukiman kumuh dan memenuhi kriteria layak agar dapat mengakses untuk perbaikan infrastruktur dan pelayanan pusat. Untuk survey lokasi dilakukan oleh tim fasilitator yang merupakan annggota dari BKM kelurahan Merjosari. Kriteria karakteristik dalam pemilihan lokasi survei di lihat dari luas pemukiman kumuh, kebutuhan akses terhadap infrastruktur dasar, penduduk, dan pelayanan dasar dan komitmen pemerintah daerah untuk melaksanakan penanganan perumahan dan pemukiman kumuh.

Tahapan ini yang dilakukan untuk memastikan kondisi dan permasalahan kawasan kumuh dan garis batas deliniasi. Pada tahap ini juga dilakukan pengamatan secara visual lokasi-lokasi yang terduga kumuh dan sekaligus melakukan veritivikasi batasan, membuat pengamatan visual dan dokumentasi objek-objek serta catat titik 
lokasi yang di anggap kumuh. Output yang di hasilkan dari tahapa ini adalah peta liniasi pemukiman kumuh, foto visual gambaran permasalahan di pemukiman kumuh, luas pemukiman kumuh, data permasalahan kumuh. Adapun langkah-langkah dari tahapan ini adalah

a. Melakukan survey sesuai dengan rute yang sudah di tetapkan lewat tahapan pertama

b. Pengamatan visual dan dokumentasi obyek-obyek berdasarkan indicator

c. Survey dilaksanakan oleh tim fasilitator kelurahan Merjosari.

d. Menghasilkan peta hasil observasi lapangan.

e. Memperoleh data profil pemukiman kumuh terdineliasi yang sudah di verititifikasi di lapangan dari hasil pengamatan yang sudah dilakukan.

Dengan adanya tahap survei lokasi sehingga tim fasilitator dapat menentukan lokasi mana yang nantinya pas untuk di laksanakan program KOTAKU sehingga pelaksanaan program nantinya dapat dilakukan dengan tepat dan memiliki output sesuai dengan yang di harapkan.

\section{Tahap Pendanaan}

Sumber pembiayaan pada program KOTAKU yang dapat digunakan dalam penataan Kelurahan Merjosari berasal dari sumber dana APBN , sumber dana APBD Provinsi Jawa Timur, Sumber Dana APBD Kota Malang, Sumber dana Swadaya Masyarakat, Sumber dana Swasta dan Perbankan. Untuk mendapatkan dana itu adapun pola-pola yang dapat dilakukan dalam menggalang sumber-sumber pendanaan dalam rangka mewujudkan visi tata bangunan dan lingkungan di kawasan perencanaan pada dasarnya berupa kegiatan-kegiatan antara lain:

a. Sosialisasi dan promosi program ke berbagai sumber pendanaan potensial baik sumber pendanaan APBD, Masyarakat, swasta baik di dalam maupun luar negeri.

b. Penyiapan/ penyelenggaraan program intensif dan kemudahan dalam penyelenggaraan investasi perizinan, dukungan program pemerintah dalam pelaksanaan investasi dan lain sebagainya.

Pemerintah daerah perlu melakukan langkah-langkah yang dapat mempercepat laju investasi sehingga penataan bangunan dan lingkungan di kawasan perencaan dapat terlaksana sesuai dengan waktu yang di jadwalkan.

\section{Tahap Pelaksanaan}

Pada dasarnya sebelum pada tahap terakhir pelaksaan program setelah setelah sebelumnya pada tahap perencanaan, survei lokasi dan tahap pendanaan sudah di laksanakan, Seluruh tahapan tersebut merupakan wadah kolaborasi.

Tahap pelaksanaan ini baik kegiatan sosial, kegiatan ekonomi maupun kegiatan infrastruktur ini terjadi di Kelurahan Merjosari sesuai dengan perencanaan yang disusun dalam dokumen rencana penanganan pemukiman kumuh dimana yang telah disahkan oleh pihak yang berwenang. Kegiatan yang dilaksanakan merupakan kegiatan pioritas penanganan baik skala kota maupun skala lingkungan yang sudah di koordinasikan.

Pelaksanaan program KOTAKU yang di laksanakan di Kelurahan Merjosari dengan penataan lingkungan ini menjadikan Kelurahan Merjosari ini sebagai kawasan bebas kumuh melalui, menciptakan lingkungan yang bersih, indah dan aman serta dapat berkelanjutan. Melalui kegiatan yang saling terintegrasi tinggi ini dan mendukung visi dari program KOTAKU (Kota Tanpa Kumuh) yang disesuaikan dengan penanganan 8 
indikator kumuh melalui penetapan prioritas perubahan bangunan dan lingkungan dikawasan ini:
a. Pengelolaan pembuangan limbah dan sampah
b. Penataan jalan lingkungan dan saluran drainase.
c. Penataan ruang terbuka hijau dan publik.
d. Penataan visual kawasan. sebagai berikut:
a. Kemendesakan penanangan (urgenitas)
b. Tingkat permasalahan
c. Dukungan sumberdaya
d. Keberlanjutan kegiatan
e. Aspek manfaat

Ada beberapa kriteria yang digunakan dalam pelaksanaan program adalah

\section{Model Implementasi Program Kotaku}

Dalam penelitian ini, peneliti menggunakan salah satu Model Implementasi top down tersebut, yaitu teori yang dikemukakan Merilee S. Grindle (dalam Subarsono, 2011:93) bahwa implementasi kebijakan publik dipengaruhi oleh 2 variabel yang fundamental, yakni isi kebijakan (content of policy) dan lingkungan implementasi (context of implementation.

Berdasarkan hasil penelitian, dapat diketahui bahwa empat variabel tersebut menjadi kriteria penting dalam implementasi suatu kebijakan. Berikut akan di bahas uraian masing-masing kondisi variabel yang mempengaruhi implementasi kebijakan Program KOTAKU di Kelurahan Merjosari:

a. Variabel isi kebijakan (content of policy)

$>$ Kepentingan - kepentingan yang mempengaruhi (Interest Affected)

$>$ Tipe manfaat (Type of benefits)

$>$ Derajat perubahan yang ingin di capai (extent of change envision)

$>$ Letak pengambilan keputusan (site of decision making)

$>$ Pelaksana program (program implementator)

$>$ Sumber-sumber daya yang di gunakan (Resources committed)

b. Variabel lingkungan kebijakan (Context of Policy)

$>$ Kekuasaan, kepentingan-kepentingan dan strategi dari aktor yang terlibat (Power, Interest, and Strategy of Actor Inolved)

$>$ Karakteristik lembaga dan rezim yang berkuasa (Insitution and Regime Characteristic)

$>$ Tingkat kepatuhan dan adanya respon dari pelaksana (Compliance and Responsiveness)

Pada dasarnya sebuah keberhasilan pelaksanaan program bergantung pada peran pemerintah dan masyarakatnya. Keduanya harus mamou menciptakan keberhasilan pada suatu program, tanpa melibatkan masyarakat, pemerintah tidak akan mencapai hasil yang optimal. Begitu pula sebaliknya tanpa peran pemerintah, pelaksaaan sebuah program tidak akan berjalan secara teratur dan tidak terarah. Selain memerlukan keterlibatan masyarakat, pelaksanaan sebuah program juga membutuhkan stretegi yang tepat agar dapat lebih efisien dari segi pembiayaan dan efektif dari segi hasil. Pemilihan strategi penying karena akan menentukan dimana peran pemerintah dan dimana peran amsyarakat, sehingga kedua belah pihak mampu berperan secara optimal. 


\section{Sasaran Kelompok}

Pertumbuhan yang ada di sektor pembangunan lingkungan perkotaan adalah akibat gelombang urbanisasi yang di pacu oleh pembangunan infrastruktur sarana dan prasarana kota yang meerupakan daya tarik sekaligus gaya dorong bagi para warga yang ingin memperoleh peluang kehidupan lebih baik. pembangunan prasarana dan sarana tidak hanya diperuntukan bagi segelintir pemanfaat namun harus bisa juga dirasakan oleh masyarakat luas, khususnya warga miskin. Adapun karakteristik yang dikategorikan perumahan kumuh dan lingkungan kumuh dari aspek fisik yaitu:

a. Merupakan satuan entitas perumahan dan pemukiman.

b. Kondisi bangunan tidak memenuhi syarat, tidak teratur dan memiliki kepadatan tinggi.

c. Kondisi sarana dan prasarana tidak memenuhi syarat, khusus untuk bidang keciptakaryaan, batasan sarana dan prasarana adalah:

$>$ Keteraturan bangunan

$>$ Drainase lingkungan

$>$ Penyediaan air bersih / minum

$>$ Pengelolaan persampahan

$>$ Pengelolaan air limbah

$>$ Pengamanan kebakaran

$>$ Ruang terbuka publik

Karakteristik tersebut selanjutnya menjadi dasar perumusan dan indikator dari gejala kumuh dalam proses indentifikasi lokasi pemukiman kumuh dan perumahan kumuh. Selain karakteristik fisik, karakteristik non fisik juga perlu diindentifikasi guna melengkapi penyebab kumuh dari aspek non fisik seperti perilaku masyarakat, kepastian bermukim, kepastian berusaha dan sebagainya.

\section{Faktor Pendukung dan Faktor Penghambat Program Kotaku}

Dalam pelaksanaan Program KOTAKU yang di laksanakan di Kelurahan Merjosari ada faktor pendukung dalam mencapai keberhasilan pada program KOTAKU dimana faktor pendukungnya berasal dari sebagian masyarakat yang mau berpartisipasi dalam pelaksanaan program KOTAKU. Partisipasi dalam pelaksanaan dengan wujud nyata partisipasi yang berupa partisipasi dalam bentuk tenaga, partisipasi dalam bentuk uang, partisipasi dalam bentuk harta benda yang berguna bagi pelaksaan pembangunan. Namun dalam hal ini belum semua masyarakat yang ikut terlibat dalam pelaksanaan yang berupa dalam bentuk tenaga di dalam kegaitan program KOTAKU yang ada di Kelurahan Merjosari.

Masyarakat yang ikut serta dalam mendukung program KOTAKU tidak hanya berpartisipasi dalam bentuk uang, tenaga, dan lain-lain namun juga ikut serta dalam keikutsertaan masyarakat dalam rapat-rapat yang di lakukan oleh pihak panitia pelaksana namun keikutsertaan tersebut hanya perwakilan dari masing masing ketua RW/RT. Sejauh mana masyarakat diberi sosialisai akan pengetahuan tentang pelaksanaan program KOTAKU dan penetapan program-program yang secara tidak langsung akan memberikan sumbangan pemikiran dalam bentuk saran untuk pelaksanaan program KOTAKU. Pada dasarnya masyarakat haruslah terlibat secara langsung dalam suatu kegiatan proyek pembangunan agar berjalan dengan sebagaimana mestinya. Sehingga dapat disimpulkan bahwa keterlibatan masyarakat dalam proses pelaksanaan program KOTAKU adalah salah satu faktor pendukung keberhasilan program KOTAKU. 
Selain ada faktor pendukung dari program KOTAKU ada pula faktor penghambat dari program KOTAKU dimana faktor penghambatnya adalah kurangnya sebagaian partisipasi masyarakat dalam pelaksanaan program KOTAKU. Padahal partisipasi masyarakat dalam mendukung berjalanannya program KOTAKU sangatlah dibutuhkan setidaknya secara sukarela menyumbangkan tenaganya di dalam kegiatan pelaksanaan program KOTAKU. Selain hal itu masyarakat juga sering lupa dalam pemeliharaan proyek-proyek pembangunan yang salah satunya sudah dilaksanakan. Oleh karena itu perlu adanya kegiatan khusus untuk menggorganisir warga guna memelihara hasil-hasil pembangunan agar manfaatnya dapat terus dinikmati dalam jangka panjang.

Faktor lain adalah kurang pahamnya masyarakat akat manfaat dari sebuah pelaksanaan program KOTAKU yang baik dan kurang tanggapnya masyarakat terhadap maslaah-masalah yang terjadi pada lingkungan sendiri. Untuk itu perlunya kesadaran masing-masing masyarakat akan adanya manfaat pada suatu pelaksanaan program KOTAKU untuk kepentingan lingkungan sendiri dan perlunya juga untuk mengumpulkan informasi yang berkaitan dengan program KOTAKU perlunya sosialisasi langsung kepada masyarakat awan agar lebih mengerti terhadap sebuah pelaksanaan program KOTAKU.

Dalam pengambilan keputusan pada umumumnya setiap program pada pemanfaatam sumberdaya dan alokasi anggarannya biasanya selalu di tetapkan sendiri oleh pemerintah pusat, yang dalam banyak hal lebih mencerminkan ke kebutuhan kelompok-kelompok kecil elit yang berkuasa dan kurang mencerminkan keinginan dan kebutuhan masyarakat banyak. Oleh karena itu, partisipasi masyarakat dalam pembangunan perlu ditumbuhkan melalui dibukanya forum yang memungkinkan masyarakat banyak berpartisipasi langsung dalam proses pengambilan keputusan tentang program-program pembangunan di Kelurahan Merjosari

Partisipasi masyarakat dalam pelaksaanprogram KOTAKU merupakan unsur penting yang sering dilupakan. Sebab, tujuan pembangunan adalah untuk memperbaiki mutu hidup masyarakat banyak sehingga pemerataan hasil pembangunan merupakan tujuan utama. Disamping itu pemanfaatan hasil pembangunan akan merangsang kemauan dan kesukarelaan masyarakat untuk selalu berpartisipasi dalam setiap pembangunan program yang akan datang.

\section{KESIMPULAN}

Berdasarkan hasil penelitian, maka peneliti menyimpulkan bahwa Implementasi Kebijakan Program KOTAKU Dalam Mensejahterakan Masyarakat di Kelurahan Merjosari, seperti berikut:

1. Pada tahap implementasi program KOTAKU di Kelurahan Merjosari dilaksanakan dalam 4 tahap utama yaitu pertama, tahap perencanaan dalam tahap ini program KOTAKU direncanakan sedemikian rupa kkegiatan apa saja yang nantinya akan dilaksanakan di Kelurahan Merjosari. Kedua, tahap survei lokasi dalam tahap ini kegiatan survei lokasi dilakukan oleh pihak faskel Kelurahan Merjosari. Dengan adanya tahap survei lokasi ini pihak faksel nantinya akan mengetahui keadaan lingkungan yang ada di Kelurahan Merjosari yang layak atau tidaknya dikatakan pemukiman kumuh dan dengan adanya surbvei lokasi. Ketiga, tahap pendanaan dalam tahap ini pendanaan sendiri berasal dari sumber APBN, sumber dana APBD Jawa Timur, sumber APBD Kota Malang, sumber dana swadaya masyarakat. Keempat, tahap pelaksana dalam tahap ini untuk program KOTAKU yang di laksanakan di Kelurahan Merjosari bahwasanya belum semuanya terlaksana hanya beberapa kegiatan yang sudah terencana seperti pembedahan rumah 
yang tidak layak, pembenahan lingkungan dan untuk permasalahan lain yang ada di masing-masing RW masih belum terencana.

2. Faktor penghambat dan faktor pendukung, untuk faktor penghambat berasal dari masyarakat itu sendiri dimana masih ada masyarakat yang kurang menjaga proyekproyek yang sudah di laksanakan. Dalam faktor pendukung ini berasal dari masyarakat bahwasanya masih ada masyarakat yang masih sukarela ikut berpartisipasi dalam pelaksanaan program bahkan masyarakat ada yang sukarela menyumbangkan dana, tenaga, dan bahan-bahan bagunan untuk pelaksanaan program. Masih adanya kesadaran masyarakat yang berinisiatif untuk memperbaiki lingkungannya sendiri sehingga secara tidak langsung nantinya demi kenyamanan masyarakat itu sendiri.

\section{SARAN}

Berdasarkan hasil penelitian dan realita dilapangan maka peneliti memberikan beberapa saran yang berkaitan dengan Implementasi program KOTAKU Dalam Mensejahterakan Masyarakat di Kelurahan Merjosari sebagai berikut: Sebagai sebuah kebijakan yang baik pengaruhnya bagi keberlangsungan masyarakat perlibatan masyarakat dalam proses pembangunan haruslah ditingkatkan dalam setiap prosesnya, baik mulai dari tahap-tahapan yang ada di program KOTAKU. Masyarakatlah yang pada dasarnya mengetahui masalah apa saja yang terjadi dilungkungan mereka masing-masing.

\section{DAFTAR RUJUKAN}

\section{Buku}

Aprilia Theresia, Krisnha S, 2015. Pembangunan Berbasis Masyarakat. Bandung: Alfabeta Bintoro Tjokroamidjojo, 1980. Perencanaan pembangunan. Jakarta: Gunung Agung

Branch, M.C, 1978. Perencanaan Kota Yang Komprehensif. Yogyakarta: Gajah Mada University Press.

Erwan Agus Purwanto, dkk, 2012. Implementasi Kebijakan Publik. Yogyakarta: Penerbit Gava Media.

Grindle, Merilee S. 1980. Politics and Policy Implementation in The Third World, Princnton University Press, New Jersey.

Islamy, M. Irfan, 2004. Prinsip-prinsip perumusan Kebijakan Negara. Jakarta: Bumi Askara.

Jones, Charles 0, 1991. Pengantar Kebijakan Publik (public policy). Penerjemah RickyIstanto.Jakarta: Rajawali.

Leo Agustino, 2017. Dasar-dasar Kebijakan Publik. Bandung: Alvabeta, CV

Mazmanian, D.A dan Sabaiter, P.A. 1983. Implementation and Public.scott Foresman and Company. USA London.

Moleong J Lexy, 2005. Metodologi Penelitian Kualitatif. Bandung: PT. Bumi aksra.

Mohammad Nazir. 1999. Metode Penelitian. Jakarta: Gelia Indonesia.

Remi, sutyastie soemitro dan prijono Tjiptoherijanto, 2002. Kemiskinan dan Ketidak merataan Diindonesia. Jakarta: PT. Rineka Cipta.

Sarman, Mukhtar\& Sajogyo, 1999. Masalah Penanggulangan kemiskinan. refleksi dari kawasan timur indonesia. Jakarta: Puspa Swara.

Sugiyono, 2016. Metode penelitian kualitatif dan kuantitatif dan R\&D. Bandung: Alfabeta cv.

Wahab, solichin abdul. 2004. Analisis dari formulasi ke implementasi kebijakan negara. Jakarta: Bumi Aksara.

William N. Dumn. 1984. Analisis Kebijaksaan publik. Yogyakarta: PT Hanindita

\section{Jurnal:}


Dewi Zuliyanti (2017) “Implementasi Program KOTAKU (Kota Tanpa Kumuh) Sebagai Model Pembangunan Infrastruktur Berbasis Masyarakat”. http://repository.radenintan.ac.id.

Fikra Sutan Purnama (2017) "Partisipasi Masyarakat Kelurahan Perigi Kecamatan Pondok Aren Kota Tanggerang Terhadap Program Pemberdayaan Kota Tanpa Kumuh". http://repository.uinjkt.ac.

Gusty Putri Dhini Rosida (2017) "Kolaborasi Perencanaan Program Kota Tanpa Kumuh (KOTAKU) " https://jurnal.uns.ac.id.Sylvia Yolanda (2018). Strategi Komunikasi Konsultan Manajemen Wilayah Dalam Program Kota Tanpa Kumuh (KOTAKU). https://jom.unri.ac.id.

\section{Undang- Undang}

Undang-undang nomor 1 tahun 2011 tentang perumahan dan kawasan pemukiman pada peraturan pemerintah

Peraturan Presiden Nomor 2 Tahun 2015 tentang rencana pembangunan jangka menengah tahun 2015-2019

Undang - undang nomor 1 tahun 2012 tentang perumahan dan kawasan pemukiman pada peraturan pemerintah

\section{Website:}

Anonymous. 2015. Implementasi Kebijakan Publik. Diakses dari http://putrassamapas.blogspot.co.id. Pada tanggal 21 Februari 2018. Pukul 16.00

Eka Putri Setiani. 2010. Pemukiman Kumuh dan Upaya Untuk Mengatasinya. Diakses dari http://pou-pout.blogspot.co.id. Pada tanggal 20 Februari 2018, pukul 14.00

Fauzia Aini. 2015. Permasalahan pemukiman Kumuh dan Penyelesaiannya. Diakses dari http://fauzia-aini.blogspot.com. Pada tanggal 20 Februari 2018, Pukul 10.00

Laode Masrun. 2009. Faktor Penyebab Tumbuh di Pusat Kota dan Kawasan Pesisir Pantai. Diakses dari http://odexyundo.blogspot.co.id. Pada Tanggal 22 Februari 2018 